\title{
The Links between Proactive Environmental Strategy, Competitive Advantages and Firm Performance: An Empirical Study in Vietnam
}

\author{
Binh Do $1, * \mathbb{1}$ and Ninh Nguyen ${ }^{2,3, *(1)}$ \\ 1 Department of Strategic Management, Thuongmai University, Ho Tung Mau Road, Hanoi 100000, Vietnam \\ 2 Department of Economics, Finance and Marketing, La Trobe Business School, La Trobe University, \\ Bundoora, VIC 3086, Australia \\ 3 Business Sustainability Research Group, Thuongmai University, Hanoi 100000, Vietnam \\ * Correspondence: binhdt@tmu.edu.vn (B.D.); ninh.nguyen@latrobe.edu.au or \\ ninhnguyen@tmu.edu.vn (N.N.); Tel.: +61-3-9479-2015 (N.N.)
}

Received: 11 May 2020; Accepted: 12 June 2020; Published: 18 June 2020

check for updates

\begin{abstract}
The acceleration of environmental problems has put firms under high pressure to assume their social and environmental responsibility. This study aims to investigate the links between proactive environmental strategy, competitive advantages and firm performance. It also explores the control effects of firm size and industry type on the adoption of such a strategy. Data were obtained from 232 firms that participated in the program on benchmarking and announcing sustainable companies in Vietnam. Findings from structural equation modelling reveal that the adoption of a proactive environmental strategy generates both differentiation and cost leadership competitive advantages. Furthermore, differentiation competitive advantages enhance firm performance in both the short term (i.e., product, financial and production performance) and long term (i.e., strategic performance). Interestingly, a proactive environmental strategy is more prevalent among larger firms and those in service industries. This study's findings provide support for firms to pursue a proactive environmental strategy and have several implications for policymakers in developing policies that aim at promoting environmental practices in firms.
\end{abstract}

Keywords: proactive environmental strategy; differentiation competitive advantage; cost leadership competitive advantage; product performance; strategic performance; production performance; financial performance; sustainability; emerging economy; Vietnam

\section{Introduction}

The acceleration of environmental problems (e.g., air pollution, natural resource depletion and climate change) is not a national issue but a global one. "Green growth", "low carbon development" and "sustainable development" have therefore attracted increasing interests in both national and international agendas. Firms in all areas have been under higher pressure to assume their social responsibility and change in ways that improve natural environment [1]. Furthermore, numerous stakeholders including governments, non-government organizations, community and others are increasingly urging these firms to minimize their impact on the natural environment [2-4]. In this situation, managers have been confronted with greater pressure to shift their strategies toward a more environmentally sustainable orientation. However, in the very narrow research line addressing the consequences of environmental strategies, answers to the questions of whether and/or when it pays to be green are still a long standing argument. Some studies reported the positive impacts of an environmental strategy on a firm's financial performance, others showed negative impacts and 
some research even did not show any significant differences in firm performances when adopting an environmental strategy [5-9].

Notably, prior empirical studies, which explored several types of competitive advantages gained from adoption of environmental strategies [3,10-12], primarily investigated companies pursuing general environmental strategies. It should be mentioned that the proactivity levels of environmental strategies differ considerably from firms to firms, depending on their commitment to environmental activities [13,14]. Additionally, the links between proactivity levels of environmental strategies and firms' competitive advantages have not yet been fully understood [15-18]. Clarification of the relationship between a proactive environmental strategy and competitive advantages achieved from such a strategy is of importance for firms to decide whether or not to pursue this type of environmental strategies.

The research line on the relationship between environmental strategy and firm performance examines various measures of firm performance [19]. A number of scholars measure firm performance of pursuing environmental strategies using financial performance indicators [11,20-24] and environmental performance indicators $[9,15,20,24-26]$. Other authors believe measures of firm performance involve not only financial and environmental performance but also operational performance $[27,28]$, market performance $[25,29,30]$ or marketing performance [31]. Regardless of many measures chosen to assess the impact of environmental strategy on firm performance, it is argued that firm performance is a complex and multidimensional phenomenon, which is inherently difficult in obtaining accurate measures. Therefore, studies can choose to focus on several measures depending on their research contexts.

It should be noted that research on the consequences of environmental strategies has been narrowed to several specific contexts. Scholars such as of Aragón-Correa et al. [32], Leonidou et al. [25] and Nulkar [33] focused on small and medium size firms, while others paid attention to a specific single industry such as the hotel sector [34-36] or wine industry [21,37,38]. There is a critical lack of research that examines proactive environmental strategies' consequences among different industries and firms with different sizes, suggesting the need for further research to consider industry types and firm sizes as control variables. Furthermore, the majority of previous studies have concentrated on firms in advanced and Western countries that have distinct managerial perceptions, cultural and regulatory contexts compared to emerging and Eastern countries [39]. Despite several relevant attempts to reveal the benefits of environmental strategies, especially those at proactive levels, there is a shortage of empirical evidence from emerging markets [29,39].

Therefore, this study helps fill these aforementioned gaps by developing and testing a model examining proactive environmental strategies and their outcomes, including competitive advantages and firm performance in the emerging market context. Specifically, while competitive advantages include differentiation advantages and cost leadership advantages, firm performance covers product, strategic, production (manufacturing) and financial performance as suggested by Nadkarni and Narayanan [40]. The present study also investigates the control impact of industry type and firm size on the adoption of a proactive environmental strategy. In addition, it focuses on Vietnam, which, emerging as the leader in low-cost manufacturing and sourcing, is an ideal export hub to reach other Southeast Asian markets. With $16 \%$ of the country's total GDP depending on the manufacturing sector [41], Vietnam has recently been confronted with various environmental challenges, such as increasing emissions, lowering resource efficiency and high levels of environmental pollution. Nevertheless, the level of environmental awareness is low in this country, and firms generally are not enthusiastically engaged in a proactive environmental strategy [17]. Providing these firms with empirical evidence about the outcomes of proactive environmental strategies such as competitive advantages and better firm performance may motivate them to pursue such strategies.

This paper has five sections. The first section presents the research gaps as well as introduces the research objectives and context. The second section provides a detailed discussion of theoretical foundation relating to proactive environmental strategies and hypotheses development. While the third section discusses the research methodology including data collection, measures and analysis 
method, the fourth section presents and discusses the results of structural equation modelling. The final section of the paper summarizes the main conclusions and offers some recommendations for managers, policymakers and future research.

\section{Literature Review and Hypotheses Development}

\subsection{Theoretical Approach}

To date, several theories such as institutional theory (IT), stakeholder theory (ST) and resource based view (RBV) theory have been utilized for the research on environmental strategies [42-44]. IT "emphasizes the importance of regulatory, normative and cognitive factors that affect firms' decisions to adopt a specific organizational practice, above and beyond the practice's technical efficiency" [16]. Within this theory, norms are imposed to firms, thus explaining the reasons why the firms adopt an environmental strategy regardless of economic benefits. In contrast with the IT, ST emphasizes that a firm's decisions are affected by its various stakeholders including regulators, activists, local communities and customers [45], which are the main factors determining the decision of the firm to adopt an environmental strategy. In addition, RBV theory rooted in Hart's [46] research of corporate environmental strategies can be used to explain the antecedents and consequences of such a strategy. This theory concentrates on internal factors that help firms gain sustained competitive advantages [47]. Amongst the previously mentioned theories, RBV theory seems to be the most used approach to explain the links between proactive environmental strategies and firm competitive advantages and performance [44,48-50]. In line with this, the present study utilized RBV as the main theoretical approach.

\subsection{Classifications of Environmental Strategies}

In efforts of minimizing the negative effects of business activities on natural environment, firms face various strategic options [43,51]. Pursuing environmental strategies not only helps firms confront with social corporate responsibility, but also give them benefits for achieving competitive advantage, market and financial performance $[10,29,52]$. However, different firms have different choices of environmental strategies over the width and depth of environmental concern areas [13]. The environmental strategy's width is the covered range of environmental areas, while the depth is the commitment level that firms respond to environmental calls. Historically, there were several approaches to the width and depth of environmental strategies that defined different levels of proactivity. Henriques and Sadorsky [44] divided firm's environmental strategies into reactive, defensive, accommodative and proactive strategy. Buysse and Verbeke [43] classified ESs into three groups of "reactive, pollution prevention and environmental leadership".

Lee and Rhee [13] considered four types of environmental strategies as "reactive, focused, opportunistic and proactive environmental strategies". Murillo-Luna et al. [14] also organized environmental strategies into four groups as "passive response, attention to legislation response, attention to stakeholder response, and total environmental quality response". Despite these various classifications, environmental strategies generally range from reactive level to more proactive one subject to commitment to environmental issues $[51,53]$. Of which, reactive environmental strategies are typical strategies for firms with minimal obligatory alterations to meet compliance, while proactive environmental strategies are adopted by firms that voluntarily take environmental initiatives to lower their negative influence on the natural environment. In the current study, we utilized Lee and Rhee's approach of a proactive environmental strategy [13], which represents the highest level of managerial perception over all management decision areas and goes beyond environmental compliance. These authors conceptualized the proactive environmental strategy as a multidimensional construct consisting of five key dimensions: product, production (manufacturing) process, organization system, supply chain and recovery, and external relationship. It is important to note that, proactive environmental strategies are adopted least by firms in several industries in Vietnam [17] that may doubt the potential effects of such strategies on the generation of competitive advantages. 


\subsection{Proactive Environmental Strategy and Competitive Advantages}

The links between environmental strategies and competitive advantages were examined by several scholars adopting the RBV approach. Peteraf and Barney [54] referred to competitive advantage as a firm's ability to create relatively more economic value than its marginal competitors by producing "greater net benefits, through superior differentiation and/or lower costs". Potter [55] (p. 18) asserted that "achieving cost leadership and differentiation are usually inconsistent, because differentiation is usually costly". However, Hill [56] suggested that the achievement of a sustained advantage may require firms to pursue both cost leadership and differentiation strategies simultaneously. Authors such as Leonidou et al. [29] and Molina-Azorín et al. [36] argued that firms that adopt a proactive environmental strategy can achieve both low-cost and differentiation competitive advantages.

Hart [46] confirmed that firm's resources and certain capabilities of pollution control and sustainable management stimulate sustainable growth. Based on RBV, he debated that these environmental-related capabilities can be considered as firms' unique resources, which help them achieve different kinds of competitive advantages [47,57]. Similarly, several researchers assert that adoption of an environmental strategy can lead to achievement of potential competitive advantages [50,58]. Specifically, a firm adopting a proactive environmental strategy can leverage its unique capabilities that in turn enhance the firm's competitive advantage [50], including differentiation competitive advantages. According to Molina-Azorín et al. [36], differentiation competitive advantage includes a distinctive image/position, higher product quality, better customer value and innovation. Higher green commitment strategy might promote firms' distinctive images compared to those of rivals $[25,52]$. Furthermore, significant improvements in firms' resources and capabilities toward environmental strategies might innovate and improve the quality of their products towards more environmentally friendly alternatives [10], creating differentiation competitive advantages over such competitors [29,59]. Moreover, firms pursuing a proactive environmental strategy often achieve environmental certificates, eco-labels or green awards such as ISO14001, which help these firms differentiate themselves in their markets $[58,60]$. Therefore, our first hypothesis is postulated as follows:

Hypothesis 1 (H1). Firms that adopt a proactive environmental strategy are likely to achieve differentiation competitive advantage.

Cost advantages are also an important issue discussed in the environmental strategy research stream. The debate on whether or not cost advantages are beneficial drivers of adopting an environmental strategy is still not conclusive. Christmann [49] suggested a moderate contribution of environmental strategies to cost competitive advantages, while others confirmed that cost leadership advantages result from adopting environmental practices in production processes [37,46]. These processes are intended to reduce manufacturing costs by minimizing inputs, saving energy, utilizing resources, and better control of the production process [37,46,61]. In addition to production cost, engaging in a proactive environmental strategy can also help firms decrease other costs such as potential liability, product-return costs and legal fees [62]. Banerjee et al. [63] asserted that firms are motivated to adopt a proactive environmental strategy since it helps lower various costs through improving processes, minimizing waste and energy as well as utilizing recyclable materials. Therefore, we propose the second hypothesis as follows:

Hypothesis 2 (H2). Firms that adopt a proactive environmental strategy are likely to achieve cost leadership competitive advantage.

\subsection{Competitive Advantages and Firm Performance}

Newbert [57] underlined that while a competitive advantage can be considered as the economic value generated from firm strategy's implementation, firm performance is the value captured 
from the commercialization of this advantage. Several empirical studies have proved the positive links between competitive advantages and firm performance. Our study contributes to the extant literature by suggesting that firms' competitive advantages derived from proactive environmental strategies enhance not only their product performance but also strategic, production and financial performance. According to Nadkarni and Narayanan [40], "high quality, high reliability, better customer support, product value-added, and product versatility" are typical indicators of product performance, representing different aspects of product quality. Strategic performance measures can be presented as managers' economic and non-economic objectives covering various aspects, such as customer satisfaction level, growth in the long term, market share development and increasing positive effects to natural environment [64]. Production or manufacturing performance indicates firm's production ability and normally includes indicators of manufacturing process, market cycle time and product system [65]. Financial performance refers to firm's profitability [66] and it frequently uses indicators such as profit margin, shareholder value, efficient cash flow, and sales revenue.

Differentiation competitive advantages derived from pursuing an environmental strategy can boost customer satisfaction, enhance repeat purchase rate, and attract new segments of environmental sensitive customers. Utilizing this competitive advantage, firms can build distinct public image, improve their reputation, enhance customer value via innovative product attributes, and strengthen their corporate social responsibility in the target markets $[8,67]$. Prior empirical studies indicate that the utilization of environmental strategies' differentiation competitive advantages can result in greater firm performance $[10,25,59]$.

Differentiation competitive advantages gained from eco-friendly features of products create a feeling of higher quality, higher reliability, better customer support and higher added value to product offerings that altogether can boost product performance $[40,68]$. Such differentiation advantages can also lead to better customer satisfaction $[55,69]$, greater long-term growth $[40,70]$, better environmental improvement and better sustainable business $[40,70]$, and therefore enhance strategic performance. Furthermore, differentiation competitive advantages focusing on innovative and eco-friendly products can drive improvements in design and production processes, as well as operational systems that are key indicators of production performance [40]. Finally, a firm's financial performance can be boosted by higher repeat purchases rate and more potential sales from new segments of ecological sensitive customers as a result of the differentiation competitive advantages gained from the adoption of proactive environmental strategies [68]. Thus, our third hypothesis is proposed as follows:

Hypothesis 3 (H3). A firm's differentiation competitive advantage based on their proactive environmental strategy enhances their (3a) product performance, (3b) strategic performance, (3c) production performance, and (3d) financial performance.

Given the common belief that higher quality products are more costly to produce [71,72], the role of cost leadership advantages in improving firm performance such as product performance is sometimes underestimated. Nevertheless, several researchers had doubt about the price-quality relationship and even proved that higher prices appear to be poor signals of higher quality [73]. Cooper [74] argued that firms with a low cost advantage still can obtain better product quality such as the domination of Japanese lower price and high quality products in 1980s. Cost leadership advantages relating to the adoption of a proactive environmental strategy results from "using energy-efficient equipment, designing energy-efficient processes, waste minimization, and making process improvements" [63], which may improve firm's product and production performance. Furthermore, a cost leadership competitive advantages derived from environmental strategies should reduce a firm's cost and improve customer saving from product usage $[6,8]$ which may lead to customer satisfaction and a high market share, therefore boosting the firm's strategic performance. Due to cost advantage, financial performance can be exalted by not only higher repeat purchase rate of frequent consumers but also acquiring sales 
from potential green customers [8,32,68], leading to potential higher profits. The aforementioned discussion leads to our fourth hypothesis as follows:

Hypothesis 4 (H4). A firm's cost leadership competitive advantage based on their proactive environmental strategy enhances their (4a) product performance, (4b) strategic performance, (4c) production performance, and (4d) financial performance.

\subsection{Control Variables: Firm Size and Industry Types}

Firm size, normally measured by the number of employees or turnover, has been considered as a control variable in studies of environmental practices and strategies. Most of these studies find that larger firms are more engaged in environmental practice. This finding can be explained by three main reasons: (1) larger firms may be under higher pressure to change to "green" from the government social organizations, stakeholders and institutions [75,76]; (2) larger firms have more resources and capabilities to commit to an environmental strategy [29,77]; and (3) larger firms tend to have more extensive environmental policies and programs [48]. With regard to proactive environmental strategies, findings on the role of firm size are inconsistent. While some scholars emphasized the active role of smaller firms in adopting a proactive environmental strategy because it is more responsive to value-chain, internal, and regulatory stakeholder pressures [75], others suggested that larger firms gain more significant values from adopting such an environmental strategy [27]. Furthermore, several scholars found essential differences between firm sizes in terms of the motivations and perceived advantages when adopting an environmental strategy [77].

Each industry with its own characteristics emits pollution differently into the environment. There has been a long-standing argument concentrating on whether a homogeneous environmental policy would work for all industries, or whether different industries should require different controls and scrutiny from the government, institutions and social groups. Several researchers have therefore emphasized the effects of industry types on environmental strategy $[25,29,63,78]$ and divided industries using different ways. Banerjee et al. [63] categorized industries into high-impact and low-impact industries and confirmed that firms in high-impact industries tended to adopt environmental practices more so than other firms. Betts et al. [78] focused on the differences in implementing environmental strategies of firms situated in dynamic and static industries. Others divided industry in terms of its harming level to the environment, namely low, moderate, and high environmental impact [25].

Given the aforementioned arguments, this study considered company size and industry type as control variables that may have impact on the adoption of a proactive environmental strategy. Figure 1 illustrates the hypothesized relationships between the variables examined in this study.

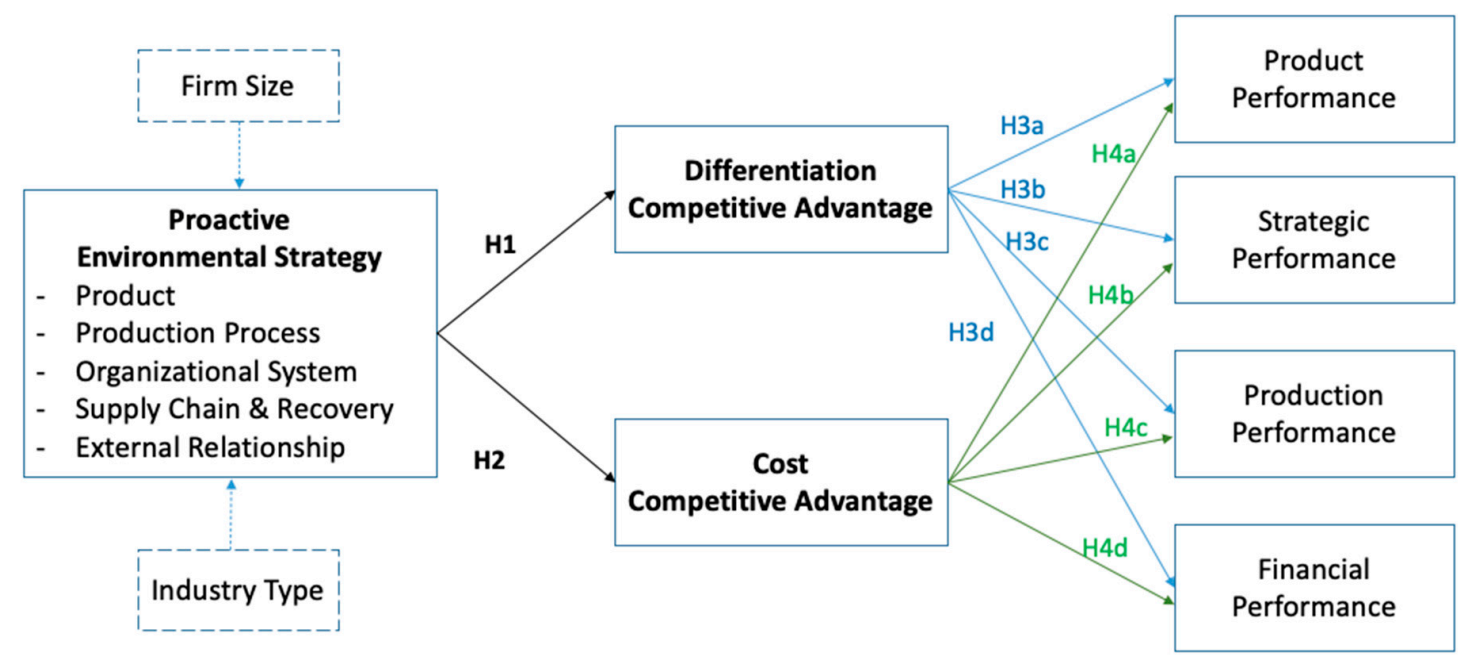

Figure 1. Hypothesized Model. 


\section{Methodology}

\subsection{Data Collection}

We conducted an online survey in eight months, from January to September 2019. The respondents were representatives of firms employing proactive environmental strategies in Vietnam. Simple random sampling was applied as this probability sampling method allows researchers to collect data from a relatively representative group of population-Wilson [79]. Additionally, it ensures that every eligible firm has an equal chance of being included in the survey. The sampling frame consisted of those firms that participated in the program on benchmarking and announcing sustainable companies in Vietnam, which was annually organized by The Vietnam Business Council for Sustainable Development (VBCSD). These firms' sustainable reports were either conducted as a separate report or integrated in the Annual Reports disclosing information of sustainable development (Ministry of Finance, 2015). Importantly, such reports were evaluated by the VBSCD using Corporate Sustainability Index (CSI). Firms that voluntarily registered to participate in the assessment were considered as those adopting proactive environmental strategies with the highest commitment level to all environmental decision areas, and they were called sustainable companies. With the referral and support from VBCS, 240 firms among more than 500 sustainable companies in 2019 agreed to participate in the survey.

We emailed the questionnaire attached with an introduction statement presenting the nature and purpose of the research as well as informed consent to each of the firms' CEOs or operation/marketing/human resource managers. After sending the questionnaire, we followed up the respondents using telephone, email or personal visits to encourage them to complete the questionnaire. Altogether, 232 questionnaires were returned (response rate was 92.24\%). Figure 2 presents information about the industry type and size of surveyed firms.
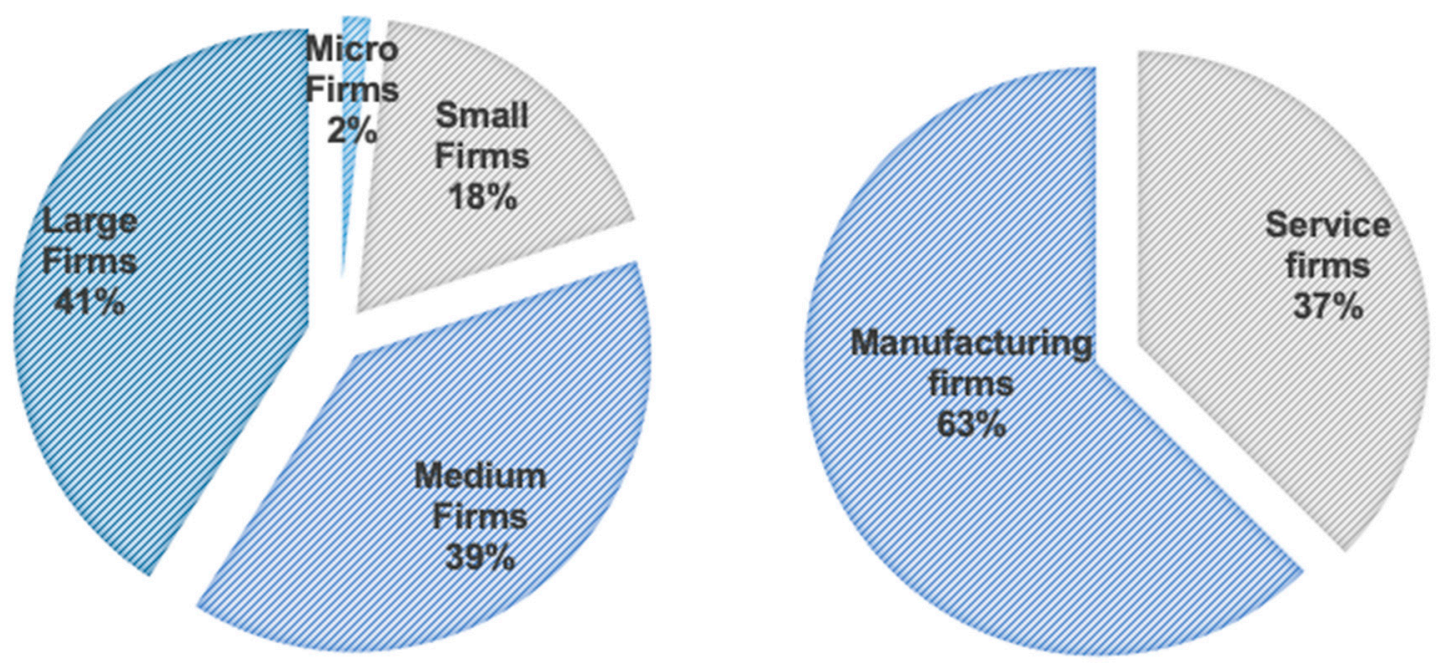

Figure 2. Surveyed Firms' Characteristics.

\subsection{Measures}

The questionnaire including the measures was designed based on forward and backward translation between English and Vietnamese (Behling and Law, 2000). A total of 12 managers of Vietnamese sustainable firms were invited to voluntarily take part in a pilot test to ensure the wordings and clarity of the measurement items. Following this test, minor changes to the wordings of several items were made. The constructs and their associated items are shown in Appendix A. 


\subsubsection{Proactive Environmental Strategy}

Following Lee and Rhee [13], we considered proactive environmental strategies to be multidimensional constructs including five dimensions of "product", "production process", "organizational system", "supply chain and recovery", and "external relationship".

- Product (PR) comprises three items relating like green concurrent engineering in new product environment, life cycle assessment and green marketing for green products.

- Production process (PP) consists of three items relating to pollution reduction practices, green production technologies and procedures for the evaluation of environmental impact in production process.

- Organizational system (OS) was measured by three items that reflects educational and training programs, organizational structure and performance assessment in response to environmental issues.

- Supply chain and recovery (SCR) were measured using three items relating to green procurement, cooperation with suppliers in environmental programs, and end-of-life product recycling programs.

- External relationship (EXR) was operationalized using three items relating to firm's relationships to key stakeholders in participating in and implementing environmental strategies. Each surveyed representative was asked to evaluate implementation degree of each decision area ranging from (1)—Strongly disagree to (7)—Strongly agree according to seven-point Likert scale.

\subsubsection{Competitive Advantages}

To measure differentiation and cost competitive advantages, seven items asking respondents to compare their firms' competitive advantages with rivals were adapted from Molina-Azorín et al. [36] and Leonidou et al. [29]. Respondents were requested to provide their responses on a seven-point scale: Extremely inferior (1), very inferior (2), somewhat inferior (3), equivalent (4), somewhat superior (5), very superior (6), or extremely superior (7).

- Differentiation competitive advantage (DCA) was measured by four items relating to green brand image, quality of environmentally friendly products, higher customer values product innovativeness.

- Cost competitive advantage (CCA) was measured by three items reflecting firm's efforts to minimize costs.

\subsubsection{Firm Performance}

In order to measure firm performance, each respondent was asked to evaluate the relative position of the firm compared to their rivals on four dimensions taken from Nadkarni and Narayanan's study [40], i.e., product performance, strategic performance, production performance and financial performance. Items contained in each scale were assessed from (1) strongly disagree to (7) strongly agree (seven-point Likert scale).

- Product performance (PRP) was measured by six items of higher quality, higher reliability, greater customer support, more added values, higher product flexibility and more reasonable price as compared to key rivals of the firm.

- Strategic performance (SP) was measured by five items relating to higher customer satisfaction, greater growth, higher market share, more positive effect to the environment and more saving costs.

- Production performance (PPE) was measured by three items that reflects efficiencies in production systems, shorter time for product launch and higher quality of operating processes.

- Financial performance (FP) was measured by three items relating to better profit margins, shareholder value and cash flow. 
It should be mentioned that Lee and Rhee [13] and Nadkarni and Narayanan [40] used the terms of "manufacturing process" and "manufacturing performance". Given that we investigated both manufacturing and service firms, we intentionally adapted these terms to "production process" and "production performance". Specifically, production process/performance refers to manufacturing-based process/performance for manufacturing firms and service production process/performance for service firms [80].

\subsubsection{Control Variables}

Firm size (FS) and industry type (IT) were included as control variables to control the effects of proactive environmental strategies on competitive advantages. Firm size can be determined by the number of employees, total assets, total sales or market value [81,82]. In this research, investigated firms were classified into four types of micro, small, medium and large firms according to Decree 39/128/NĐ-CP of Prime Minister of Vietnam, which combined three criteria of number of employees, total sales and total assets. These firms were in two main industries, i.e., manufacturing and services industry listed by the VBCSD.

\subsection{Methods for Data Analysis}

We first checked the assumptions for multivariate analysis using multivariate diagnostic tests, followed by an examination of the possibility of common method bias using Harman's single-factor method and unmeasured latent methods factor [83]. After that, we used structural equation modelling (SEM), applying the elliptical reweighted least-squares (ERLS) estimation method in EQS (Multivariate Software Inc., Temple City, CA, USA), to validate the measures and test the proposed hypotheses $[29,84]$. While SEM has been widely used in environmental strategy and sustainability research [85-89], ERLS was selected because it can effectively handle both normal data and non-normal data [29,90]. Importantly, SEM further advances ordinary regression models by enabling the evaluation of complex models including various hypothesized relationships between multiple dependent and independent variables [91]. Goodness-of-fit indices used to evaluate measurement models and structural models include chi-square to degree of freedom ratio $\left(\frac{\chi^{2}}{\mathrm{df}}<3.0\right)$, Bentler-Bonett normed fit index (NFI $\left.>0.9\right)$, Bentler-Bonnet non-normed fit index (NNFI $>0.9)$, comparative fit index (CFI $>0.9)$ and root mean square error of approximation (RMSEA < 0.08) [91,92]. In addition to these multivariate analysis techniques, descriptive statistics and reliability analysis using Cronbach's alpha were also used.

\section{Results and Discussion}

\subsection{Multivariate Diagnostic Tests}

Before conducting multivariate analysis, we checked the multivariate assumptions, including normality of distribution, multicollinearity, multivariate outliers and homoscedasticity of residuals to help ensure the robustness of empirical results. Skewness and kurtosis were calculated using SPSS (IBM, New York, NY, USA) to detect normality of distribution. The results showed that the highest absolute value of skewness was 6.08 , while the highest absolute value of kurtosis was 16.23 . These values were outside twice the standard error $( \pm 1.96)$, indicating non-normality of data [91]. In the context of such significant non-normality, ERLS based on EQS was chosen as the estimation method because it provides unbiased parameter estimates for both normal and non-normal data, and especially has superior performance for non-normal data [90]. To examine multicollinearity, we calculated tolerance value and variance inflation factor (VIF). The results demonstrated that the highest statistical value of VIF was 1.88, while the lowest tolerance value was 0.53 . These values suggested the absence of multicollinearity between the variables [91].

Using regression analysis with firm performance being dependent variable and the rest of the constructs being independent variables, we obtained Mahalanobis distance $(p<0.001)$ and studentized deleted residual (above \pm 4.00 ) to detect multivariate outliers [93]. The results demonstrated that our 
data were free of multivariate outliers. The regression analysis also allowed us to produce scatterplot of standardized residuals against standardized predicted values, which helps examine the assumptions of linearity and homoscedasticity of residuals. As illustrated in Appendix B, there was an absence of any clear patterns in the spread of points and the points tended to cluster toward the center of the scatterplot. Both of these together ensured the assumptions of linearity and homoscedasticity [91].

\subsection{Common Method Effects}

According to the Harman's single-factor method, all items included in the hypothesized model were subjected to a principal component analysis with Varimax rotation using SPSS 24.0 (IBM, New York, NY, USA). The unrotated factors solutions showed eight separate factors with eigenvalues value above 1.0 , which explained $43 \%$ of the total variance. Then, the unmeasured latent methods factor test was performed using second-order confirmatory factor analysis (CFA). Accordingly, all items were restricted to load on a single factor [94]. Fit statistics of that model were $\chi^{2}=6116.67, p=0.00$, $\frac{\chi 2}{\mathrm{df}}=5.50, \mathrm{NFI}=0.81, \mathrm{NNFI}=0.81, \mathrm{CFI}=0.83, \mathrm{RMSEA}=0.17$. The values of these indices were below the commonly accepted cutoff scores, indicating a poor fitting model [92]. The combinational results of the two techniques confirmed that common method bias was not a problem in our study.

\subsection{Measure Validation}

As previously mentioned, SEM based on EQS was used to assess the validity of the measurement model including the constructs of proactive environmental strategies, differentiation advantages, cost advantages, product performance, strategic performance, production performance, and financial performance.

CFA confirmed that all factors loaded highly on designated constructs and key results are illustrated in Table 1. The resultant fit indices were $\chi^{2}=2544.32, p=0.00, \mathrm{df}=1112, \frac{\chi 2}{\mathrm{df}}=2.29$, $\mathrm{NFI}=0.91, \mathrm{NNFI}=0.93, \mathrm{CFI}=0.93, \mathrm{RMSEA}=0.07$, suggesting that the goodness-of-fit estimate was acceptable.

Cronbach's alphas ranged from 0.78 to 0.93 , while composite reliability (CR) values fluctuated between 0.72 to 0.87 , which confirmed a reliable measurement of the hypothesized model. In addition, the results also ensured convergent validity as each item had a $t$-value higher than 4.0, standardized loadings were greater than $0.5, \mathrm{CR}$ was higher than 0.7 , average variance extracted (AVE) was above 0.5, and CR was greater than AVE [90]. According to Fornell and Larcker [95], discriminant validity is ensured if the square root of the AVE of each construct is greater than the bivariate correlation coefficient for each pair of the constructs. Table 2 shows that the square root of the AVE fluctuated from 0.73 to 0.87 , while the highest bivariate correlation value between the constructs was 0.69 . Therefore, the discriminant validity of the measures was satisfied.

It should be mentioned that "product" had a low correlation with two elements of proactive environmental strategies, namely, "organizational system" $(r=0.09)$ and "external relationship" $(\mathrm{r}=0.08)$. However, it had a significant correlation with "production process" $(\mathrm{r}=0.27)$ and "supply chain and recovery" $(r=0.37)$. Thus, we ran another CFA without "product" dimension. However, the resulting fit indices were worse than those of the previous model, including product as an element of proactive environmental strategy. This, along with inheriting Lee and Rhee's research results [13], let us retain product as a key dimension of proactive environmental strategy in the present study. 
Table 1. Measurement Model Results.

\begin{tabular}{|c|c|c|c|c|c|c|c|c|}
\hline Constructs & Items & $\begin{array}{l}\text { Standardized } \\
\text { Loadings }\end{array}$ & $t$-Value & $\alpha$ & CR & AVE & Mean & SD \\
\hline \multirow{3}{*}{$\begin{array}{l}\text { Product } \\
\text { (PR) }\end{array}$} & & & & \multirow{3}{*}{0.87} & \multirow{3}{*}{0.82} & \multirow{3}{*}{0.69} & 3.17 & 1.05 \\
\hline & PR2 & 0.76 & 6.59 & & & & 3.22 & 1.25 \\
\hline & PR3 & 0.88 & 5.32 & & & & 3.13 & 1.32 \\
\hline \multirow{3}{*}{$\begin{array}{l}\text { Production } \\
\text { process } \\
\text { (PP) }\end{array}$} & & & & \multirow{3}{*}{0.88} & \multirow{3}{*}{0.81} & \multirow{3}{*}{0.66} & 3.97 & 1.33 \\
\hline & PP2 & 0.82 & 11.52 & & & & 3.69 & 1.46 \\
\hline & PP3 & 0.87 & 10.79 & & & & 4.01 & 1.40 \\
\hline \multirow{3}{*}{$\begin{array}{l}\text { Organizational } \\
\text { System } \\
\text { (OS) }\end{array}$} & & & & \multirow{3}{*}{0.84} & \multirow{3}{*}{0.80} & \multirow{3}{*}{0.60} & 3.07 & 1.12 \\
\hline & OS1 & 0.78 & $*$ & & & & 3.06 & 1.35 \\
\hline & OS2 & 0.71 & 10.54 & & & & 3.13 & 1.29 \\
\hline \multirow{2}{*}{$\begin{array}{l}\text { Supply chain } \\
\text { and recovery } \\
\text { (SCR) }\end{array}$} & SCR2 & 0.78 & 7.47 & \multirow{2}{*}{0.93} & \multirow{2}{*}{0.86} & \multirow{2}{*}{0.62} & 3.24 & 1.32 \\
\hline & SCR3 & 0.82 & 8.95 & & & & 3.78 & 1.35 \\
\hline \multirow{4}{*}{$\begin{array}{l}\text { External } \\
\text { relationship } \\
\quad(\mathbf{E X R})\end{array}$} & & & & \multirow{4}{*}{0.84} & \multirow{4}{*}{0.80} & & 3.14 & 1.16 \\
\hline & EXR1 & 0.84 & $*$ & & & & 3.15 & 1.38 \\
\hline & EXR2 & 0.72 & 8.12 & & & 0.68 & 3.04 & 1.35 \\
\hline & EXR3 & 0.91 & 8.32 & & & & 3.22 & 1.37 \\
\hline & & & & & & & 3.75 & 1.22 \\
\hline Differentiation & DCA1 & 0.91 & $*$ & & & & 4.13 & 1.47 \\
\hline competitive & DCA2 & 0.82 & 16.2 & 0.93 & 0.87 & 0.75 & 4.01 & 1.55 \\
\hline (DCA) & DCA3 & 0.90 & 15.7 & & & & 3.29 & 1.42 \\
\hline & PRP1 & 0.68 & * & & & & 3.32 & 1.46 \\
\hline Product & PRP2 & 0.83 & 6.63 & & & & 4.16 & 1.12 \\
\hline performance & PRP3 & 0.75 & 7.13 & 0.88 & 0.83 & 0.53 & 3.85 & 1.25 \\
\hline$(\mathbf{P R P})$ & PRP4 & 0.71 & 7.51 & & & & 3.72 & 1.31 \\
\hline & PRP5 & 0.72 & 7.57 & & & & 3.55 & 1.23 \\
\hline & PRP6 & 0.65 & 7.47 & & & & 3.87 & 1.34 \\
\hline & & & & & & & 3.73 & 1.17 \\
\hline & SP1 & 0.68 & $*$ & & & & 4.05 & 1.36 \\
\hline $\begin{array}{c}\text { Strateg1c } \\
\text { performance }\end{array}$ & SP2 & 0.83 & 9.29 & & & & 3.67 & 1.32 \\
\hline $\begin{array}{c}\text { performance } \\
\text { (SP) }\end{array}$ & SP3 & 0.72 & 9.21 & 0.90 & 0.85 & 0.55 & 3.22 & 1.34 \\
\hline & SP4 & 0.71 & 8.31 & & & & 4.06 & 1.33 \\
\hline & SP5 & 0.75 & 7.88 & & & & 3.65 & 1.32 \\
\hline & & & & & & & 3.29 & 1.11 \\
\hline Production & PPE1 & 0.79 & $*$ & 084 & 079 & 063 & 3.05 & 1.49 \\
\hline performance & PPE2 & 0.78 & 7.32 & 0.84 & 0.79 & 0.63 & 3.79 & 1.44 \\
\hline (PPE) & PPE3 & 0.81 & 7.08 & & & & 3.02 & 1.36 \\
\hline & & & & & & & 3.28 & 1.03 \\
\hline Financial & FP1 & 0.83 & $*$ & 088 & 081 & 053 & 3.14 & 1.45 \\
\hline $\begin{array}{l}\text { perrormance } \\
\text { (FP) }\end{array}$ & FP2 & 0.63 & 5.72 & 0.88 & 0.81 & 0.53 & 3.12 & 1.47 \\
\hline$($ IF) & FP3 & 0.70 & 6.34 & & & & 3.57 & 1.39 \\
\hline
\end{tabular}

Note: * Item fixed to set the scale; SD: Standard deviation; Fit statistics: $\chi^{2}=2544.32, p=0.00, \mathrm{df}=1112, \frac{\chi^{2}}{\mathrm{df}}=2.29$, $\mathrm{NFI}=0.91, \mathrm{NNFI}=0.93, \mathrm{CFI}=0.93, \mathrm{RMSEA}=0.07$. 
Table 2. The Matrix of Correlation.

\begin{tabular}{|c|c|c|c|c|c|c|c|c|c|c|c|}
\hline Constructs & 1 & 2 & 3 & 4 & 5 & 6 & 7 & 8 & 9 & 10 & 11 \\
\hline 1. Product & 0.83 & & & & & & & & & & \\
\hline 2. Production process & 0.27 & 0.81 & & & & & & & & & \\
\hline 3. Organizational system & 0.09 & 0.22 & 0.77 & & & & & & & & \\
\hline 4. Supply chain and recovery & 0.37 & 0.12 & 0.45 & 0.79 & & & & & & & \\
\hline 5. External relationship & 0.08 & 0.56 & 0.36 & 0.21 & 0.82 & & & & & & \\
\hline 6. Differentiation advantage & 0.18 & 0.02 & 0.01 & 0.69 & 0.41 & 0.87 & & & & & \\
\hline 7. Cost leadership advantage & 0.26 & 0.69 & 0.45 & 0.33 & 0.39 & 0.42 & 0.76 & & & & \\
\hline 8. Product performance & 0.01 & 0.35 & 0.13 & 0.13 & 0.06 & 0.15 & 0.27 & 0.73 & & & \\
\hline 9. Strategic performance & 0.23 & 0.47 & 0.32 & 0.67 & 0.25 & 0.03 & 0.14 & 0.31 & 0.74 & & \\
\hline 10. Production performance & 0.11 & 0.05 & 0.13 & 0.01 & 0.36 & 0.45 & 0.27 & 0.03 & 0.08 & 0.79 & \\
\hline 11. Financial performance & 0.23 & 0.37 & 0.22 & 0.27 & 0.55 & 0.33 & 0.64 & 0.16 & 0.43 & 0.31 & 0.73 \\
\hline
\end{tabular}

Note: Correlations above 0.18 are significant at the 0.01 level; correlations above 0.15 are significant at the 0.05 level; diagonal value shows the square root of AVE of construct.

\subsection{Hypotheses Testing}

We used the ERLS technique to test the hypothesized links among the constructs, given the limitation of sample size [96]. Composite scores were specified as manifest variables of each latent indicators of constructs. As shown in Figure 3, the model diagnostics generated satisfactory fit indices for the structural model.

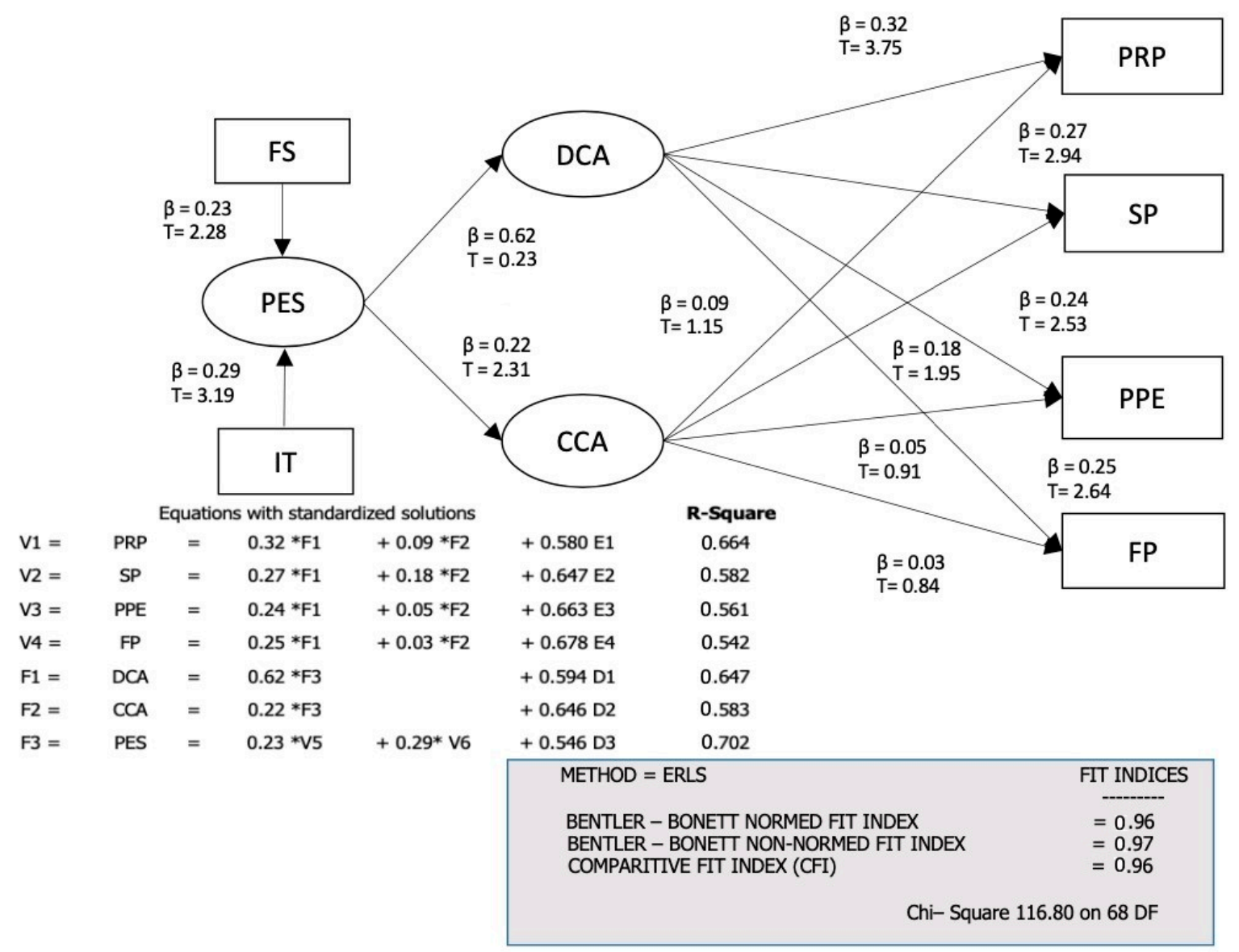

Figure 3. Full model estimates—standardized parameters.

The path coefficients $(\beta)$ that represent the standardized estimates, corresponding $t$-values and $p$-value were shown in Table 3. 
Table 3. The hypothesized model results.

\begin{tabular}{clccc}
\hline & \multicolumn{1}{c}{ Hypothesized Paths } & $\boldsymbol{\beta}$ & $\boldsymbol{t}$-Value & $\boldsymbol{p}$-Value \\
\hline H1 & Proactive environmental strategy $\rightarrow$ Differentiation competitive advantage & 0.62 & 7.23 & 0.00 \\
H2 & Proactive environmental strategy $\rightarrow$ Cost leadership competitive advantage & 0.22 & 2.31 & 0.04 \\
H3a & Differentiation competitive advantage $\rightarrow$ Product performance & 0.32 & 3.75 & 0.00 \\
H3b & Differentiation competitive advantage $\rightarrow$ Strategic performance & 0.27 & 2.94 & 0.01 \\
H3c & Differentiation competitive advantage $\rightarrow$ Production performance & 0.24 & 2.53 & 0.03 \\
H3d & Differentiation competitive advantage $\rightarrow$ Financial performance & 0.25 & 2.64 & 0.02 \\
H4a & Cost leadership competitive advantage $\rightarrow$ Product performance & 0.09 & 1.15 & 0.56 \\
H4b & Cost leadership competitive advantage $\rightarrow$ Strategic performance & 0.18 & 1.95 & 0.04 \\
H4c & Cost leadership competitive advantage $\rightarrow$ Production performance & 0.05 & 0.91 & 0.40 \\
H4d & Cost leadership competitive advantage $\rightarrow$ Financial performance & 0.03 & 0.84 & 0.62 \\
& Control Effects & & & \\
& Firm size $\rightarrow$ Proactive environmental strategy & 0.23 & 2.28 & 0.04 \\
& Industry type $\rightarrow$ Proactive environment strategy & 0.29 & 3.19 & 0.03 \\
\hline
\end{tabular}

Note: Fit statistic: $\chi^{2}=116.80, p<0.001, \mathrm{df}=68, \frac{\chi^{2}}{\mathrm{df}}=1.69, \mathrm{NFI}=0.96, \mathrm{NNFI}=0.97, \mathrm{CFI}=0.96, \mathrm{RMSEA}=0.07$.

To further evaluate the robustness of the empirical results, robust methodology for non-normal data based on EQS was applied to improve the performance of test statistics [97,98]. The Yuan-Bentler scaled chi-square test $(\bar{T})$, robust standard errors, and three residual-based test statistics (i.e., Residual-based test statistic - TRES, Yuan-Bentler residual-based test statistic - TYB (RES), and Yuan-Bentler residual-based F-statistic TF (RES)) were computed. The results in Table 4 revealed that the data performed well under a variety of conditions [99], confirming the robustness of the hypothesized model.

Table 4. Test statistics for robust procedure.

\begin{tabular}{ccccccc}
\hline & \multirow{2}{*}{ Statistic } & & $\boldsymbol{N}$-Value & & \multicolumn{3}{c}{ Parameter Estimates } \\
\cline { 5 - 7 } & & & & Est. & Standard Error & $\mathbf{z}$ \\
\hline $\bar{T}$ & 11.492 & 0.175 & $\sigma_{e 1}^{2}$ & 61.125 & 12.063 & 4.563 \\
TRES & 12.593 & 0.123 & $\sigma_{e 2}^{2}$ & 72.437 & 8.871 & 8.286 \\
TYB(RES) & 10.823 & 0.212 & $\sigma_{e 3}^{2}$ & 66.617 & 9.128 & 7.500 \\
TF(RES) & 1.433 & 0.200 & $\sigma_{e 4}^{2}$ & 65.833 & 15.253 & 4.267 \\
\hline
\end{tabular}

The findings indicated that pursuing a proactive environmental strategy helped Vietnamese companies achieve both differentiation $C A(\beta=0.62, t=7.23, p=0.00)$ and cost leadership $C A(\beta=0.22$, $\mathrm{t}=2.31, p=0.04)$. This supports the finding of Junquera and Barba-Sánchez [21] that "environmental proactivity leads to the creation of significant competitive advantages both in differentiation and cost leadership". The confirmation of H1 and H2 also extends the study of Leonidou et al. [29] in which a pro-environmental export business strategy only leads to a product differentiation competitive advantage. Our results confirm that adoption of proactive environmental strategies not only helps differentiate firms' resources, capabilities and images, but also lowers their costs, such as by minimizing waste and improving the efficiency of energy consumption [100,101]. It should be mentioned that proactive environmental strategies have greater influence on differentiation competitive advantages than cost leadership competitive advantages. As such, adopting a proactive environmental strategy can be of utmost importance in building a firm's distinct image and positioning.

Furthermore, the effects of differentiation competitive advantages on product performance $(\beta=0.32, \mathrm{t}=3.75, p=0.00)$, strategic performance $(\beta=0.27, \mathrm{t}=2.94, p=0.01)$, production performance $(\beta=0.24, \mathrm{t}=2.53, p=0.03)$ and financial performance $(\beta=0.25, \mathrm{t}=2.64, p=0.02)$ were all positive and statistically significant. All the hypothetical links proposed in the third hypothesis $\left(\mathrm{H}_{3}\right)$ were thus confirmed. These findings support past research indicating that if a firm's environmental strategy is proactive, it can generate differentiation competitive advantages which, in turn, improve the firm's performance in various areas $[25,38,102,103]$. Essentially, firms' differentiation competitive advantages derived from their proactive environmental strategy can enhance their products' quality and reliability and add more value to such products. This distinctive advantage also stimulates firms in retaining recent customers, achieving new green-sensitive consumers, enhancing better long-term growth, 
and reaching better market share, higher profit margin and higher shareholder value. Moreover, the differentiation advantage derived from proactive environmental strategies promotes organizational production systems to be more efficient, subsequently shortening product launch time to market being and improving production process.

Finally, our findings regarding the impact of cost leadership competitive advantages on firm performance $(\mathrm{H} 4)$ were mixed. While such a competitive advantage harnessed strategic performance ( $\beta=0.18, t=1.95, p=0.04)$, it had no significant effect on the achievement of product performance $(\beta=0.09, \mathrm{t}=1.15, p=0.56)$, production performance $(\beta=0.05, \mathrm{t}=0.91, p=0.40)$, and financial performance $(\beta=0.03, t=0.84, p=0.62)$. Our finding regarding the insignificant relationship between cost leadership competitive advantages and financial performance is in line with that reported by Leonidou et al. [29]. The mixed results found in this study might make it difficult for managers to decide whether to pursue a proactive environmental strategy-based cost leadership advantage. In the short term, if firms consider environmental expenditures as a cost, they might not achieve better product, production and financial performance. However, if firms consider environmental expenditures as an investment in the long term, they can obtain higher strategic performance by creating better customer satisfaction, higher quality of processes, shorter market cycle times, better environmental improvement and longer term growth.

\subsection{Effects of Control Variables}

We examined the potential effects of two control variables (i.e., firm size and industry type) on the adoption of a proactive environmental strategy. The results indicated that both variables had a potential control effect on proactive environmental strategies. Regarding firm size, it is revealed that larger firms were more obvious in pursuing a proactive environmental strategy than small ones $(\beta=0.23, t=2.28$, $p=0.04)$. This is in agreement with the study performed by Leonidou et al. [29] but in contrast with the research result of López-Gamero \& Molina-Azorín [31]. Possible explanations include that larger firms possess more resources such financial and personnel ones for pursuing a proactive environmental strategy, and that they tend to have better capabilities for dealing with environmental problems [29]. Furthermore, these larger firms are more likely to achieve economies of scale to lower costs and assume risks when adopting a proactive environmental strategy compared with their smaller counterparts.

We also found that service firms tend to pursue a proactive environmental strategy more positively than manufacturing firms $(\beta=0.29, \mathrm{t}=3.19, p=0.03)$. A reason for this may be because firms in Vietnam's manufacturing sectors who want to adopt proactive environmental strategies are often required to invest a significant amount of money and effort in greening their manufacturing technologies and processes. This is because these manufacturing firms, especially those in textile, garment and shoe manufacturing sectors, have greater negative impact on the environment than service firms. Such financial barriers may impede the adoption and implementation of a proactive environmental strategy among manufacturing firms, especially those of small and medium size.

\section{Conclusions and Implications}

Given that environmental parameters are complicated and that the proactivity levels of environmental strategies differ in different countries and industries [44,75], the consequences of proactive environmental strategies should vary across different contexts. Research on environmental strategies and their outcomes in emerging markets is scarce. We have therefore sought to examine the outcomes of proactive environmental strategies, which represent firms' high levels of commitment to tackle environmental issues through the integration of five dimensions, namely, product, production process, organizational systems, supply chain and recovery, and external relationship [13] in the context of Vietnam. Overall, our study highlights the proactive environmental strategy-competitive advantage-firm performance mechanism. It also supports the RBV that environmental strategies can be considered as dynamic capabilities that enhance superior competitive and firm performance. To the best of our knowledge, this study is the first attempt to evaluate the integrative impact of both cost 
leadership and differentiation competitive advantages on the four dimensions of firm performance (i.e., product, financial, production and strategic performance).

The first conclusion is that the adoption of a proactive environmental strategy can lead to both differentiation and cost leadership competitive advantages. This assertion provides empirical support for the proposition that proactive corporate environmental strategies play an instrumental role in generating competitive advantages [101], and it extends previous research in the literature [21,29]. Given the strong impact of proactive environmental strategies on differentiation competitive advantages, our study emphasizes that such a strategy can provide firms with a distinctive position in the market. It should be noted that our study enriches environmental sustainability research by operationalizing proactive environmental strategies as multidimensional constructs, including factors such as product, organizational system, production process, supply chain and external relationship. In the context of Vietnam, an emerging country that is a manufacturing hub with low awareness of environmental issues [17], our first conclusion provides compelling evidence to motivate Vietnamese firms to adopt proactive environmental strategies as value-creating strategies.

The second conclusion involves the effects of those competitive advantages gained from adopting a proactive environmental strategy on firm performance. Viewing firm performance from the strategic management perspective, our research contributed to the literature by comprehensively and systematically examining different indicators of firm performance, including product performance, strategic performance, production performance and financial performance. Adapted from Nadkarni and Narayanan [40], strategic performance is measured by growth indicators in the long term (during the last three years), while product performance, production performance and financial include short-term indicators at the surveyed time. Our findings reveal that while differentiation competitive advantages exert a positive influence on all dimensions of firm performance, low cost advantages are positively related to only one dimension, i.e., strategic performance. Our study contributes to the literature by highlighting the integrative effects of differentiation competitive advantages on various indicators of firm performance, which have been partially investigated in prior studies $[10,25,38,59,102,103]$. Essentially, we can conclude that differentiation competitive advantages contribute greatly to firm performance in both the short and long term, while cost leadership advantages have a bigger contribution to long-term performance.

There are several possible explanations for the second conclusion. Essentially, differentiation competitive advantages derived from environmental strategies helps firms meet expectations of targeted green customers and enhance their satisfaction. Such green consumers are often more highly educated, long-term oriented and willing to spend more on eco-friendly products and services [85,104-106], hence playing an important role in improving firms' short- and long-term performance from product, strategic, production and financial performance perspectives. In contrast, lower prices offered by firms with cost leadership competitive advantages may make the "greenness of products" less visible to environmentally sensitive consumers and result in unfavorable financial benefits in the short term. However, such consumers, in the long term, may become more aware of the environmental friendliness of the firm and become more satisfied with the products. In addition, they may also show a tendency to purchase more because of the lower price of the products. This results in favorable long-term strategic performance. Our study therefore highlights time gaps relating to the impact of competitive advantages types on firm performance: while differentiation advantages have a more direct effect on firm performance, it takes much longer to boost the firm performance for cost leadership competitive advantages.

The last conclusion reveals that larger and service firms tend to be more active in adopting proactive environmental strategies compared to smaller and manufacturing firms in Vietnam. The finding about the impact of firm size is in line with that in prior studies [29,77], suggesting that firms with greater sales and assets are more likely to implement proactive environmental strategies. Given that most prior studies have focused on a single industry or sector, our study contributes to the literature by providing fresh insight into the effects of different industry types on the adoption of environmental strategies. 
Our research has several implications for managers and policymakers. Given the benefits of achieving both differentiation and cost leadership competitive advantages from adoption of proactive environmental strategies, firms' managers should consider implementing environmental strategies that proactively and comprehensively engage environmental issues in all decision areas, rather than adopting a compliant, reactive approach to environmental issues. To successfully adopt such proactive environmental strategies, firms need to promote their products/services, production process, organization system, supply chain and external relationship towards a more eco-friendly orientation. Importantly, firms that prefer to enhance their performance (i.e., product, financial, production and strategic performance) in both the short and long term should focus on generating differentiation competitive advantages based on proactive environmental strategies. Specifically, these strategies should aim to create a green brand image and highlight the innovativeness, better quality and higher value of firms' products and services. Firms can also seek to obtain low cost competitive advantages by improving productivity and economies of scale, which can enhance product, financial and production performance in the long term.

Public policymakers and environmental organizations should try to communicate to firms' managers that the adoption of a proactive environmental strategy will help enhance their firms' performance in the long run. The government can play a supportive role by enriching environmental education programs and stimulating successful case studies of firms pursuing proactive environmental strategies. Public policymakers should also conduct surveys, interviews and discussion groups that aim at understanding the barriers preventing firms from adopting proactive environmental strategies. This will enable policymakers to effectively develop incentive schemes and enforcement policies that can encourage Vietnamese firms to adopt various environmental strategies, especially the proactive one. It would be also desirable to have different supporting schemes and control processes for firms in different industries. For example, more government financial incentives (e.g., tax allowances, grants, loans and government procurement) should be prioritized for firms in manufacturing sectors, given that the significant amount of financial resources required for investing in green technologies and energy efficiency may hamper their adoption of proactive environmental strategies.

Future research studies can overcome the limitations of and expand our study in several ways. We investigated the consequences of the adoption of proactive environmental strategies using a quantitative method, which can be enhanced by a qualitative approach in the future for richer information about the outcomes of such an environmental strategy. It would be also desirable for future research to examine the consequences of pursuing proactive environmental strategies in other contexts (e.g., countries and industries) that have more complex regulatory conditions. Moreover, more control variables such as mangers' pro-environmental orientations and characteristics could be included. Finally, to clarify the effects of proactive environmental strategies on competitive advantages and firm performance in the long term, a longitudinal research should be performed.

Author Contributions: Conceptualization, B.D. and N.N.; methodology, B.D. and N.N.; formal analysis, B.D.; investigation, B.D.; writing-original draft preparation, B.D. and N.N.; writing-review and editing, B.D. and N.N. All authors have read and agreed to the published version of the manuscript.

Funding: This research received no external funding.

Conflicts of Interest: The authors declare no conflict of interest. 


\section{Appendix A}

Table A1. Constructs and Items.

\begin{tabular}{|c|c|c|c|}
\hline Constructs & Item & Item Description & Source \\
\hline \multirow{3}{*}{ Product } & PR1 & $\begin{array}{l}\text { We use concurrent engineering in new product } \\
\text { development to improve our products' }\end{array}$ & \multirow{16}{*}{$\begin{array}{l}\text { Adapted from Lee } \\
\text { and Rhee [13] }\end{array}$} \\
\hline & PR2 & environmental performance & \\
\hline & PR3 & $\begin{array}{l}\text { We have life cycle assessment system for our products } \\
\text { We have green marketing program for our products }\end{array}$ & \\
\hline \multirow{4}{*}{ Production Process } & & We have programs and practices that reduce & \\
\hline & PP1 & environmental pollution in our production area & \\
\hline & PP2 & $\begin{array}{l}\text { We have greener technologies in our } \\
\text { production processes }\end{array}$ & \\
\hline & PP3 & $\begin{array}{l}\text { We have official procedures for } \\
\text { environmental evaluation }\end{array}$ & \\
\hline \multirow{3}{*}{ Organizational System } & OS1 & $\begin{array}{l}\text { We provide environmental training and educational } \\
\text { programs to our employees }\end{array}$ & \\
\hline & OS2 & $\begin{array}{l}\text { We have a specialized division to deal with our firm's } \\
\text { environmental issues }\end{array}$ & \\
\hline & OS3 & $\begin{array}{l}\text { We have programs to measure and assess our } \\
\text { environmental performance }\end{array}$ & \\
\hline \multirow{3}{*}{$\begin{array}{l}\text { Supply chain and } \\
\text { recovery }\end{array}$} & CAF1 & $\begin{array}{l}\text { Our procurement is concerned with environmentally } \\
\text { friendly products }\end{array}$ & \\
\hline & CAF2 & $\begin{array}{l}\text { We provide environmental support and collaborative } \\
\text { works to our suppliers }\end{array}$ & \\
\hline & CAF3 & We conduct product re-use programs & \\
\hline \multirow{3}{*}{ External Relationship } & EXR1 & $\begin{array}{l}\text { We have good relationships with communities, local } \\
\text { authorities, NGOs, socio-political organizations }\end{array}$ & \\
\hline & EXR2 & $\begin{array}{l}\text { We voluntarily implement environmental protection } \\
\text { programs }\end{array}$ & \\
\hline & EXR3 & $\begin{array}{l}\text { We periodically publish transparent environmental } \\
\text { information about our firm }\end{array}$ & \\
\hline \multirow{4}{*}{$\begin{array}{l}\text { Differentiation } \\
\text { competitive advantage }\end{array}$} & DCA1 & $\begin{array}{l}\text { We create a green brand image to identify the firm in } \\
\text { the market }\end{array}$ & \multirow{12}{*}{$\begin{array}{l}\text { Adapted from } \\
\text { Leonidou et al. [29] } \\
\text { and Molina-Azorín } \\
\text { et al. [36] }\end{array}$} \\
\hline & DCA2 & $\begin{array}{l}\text { Our environmentally friendly products have better } \\
\text { quality than our rivals }\end{array}$ & \\
\hline & DCA3 & $\begin{array}{l}\text { Our environmentally friendly products add more value } \\
\text { for customers }\end{array}$ & \\
\hline & DCA4 & $\begin{array}{l}\text { Our environmentally friendly products are highly } \\
\text { innovative }\end{array}$ & \\
\hline \multirow{2}{*}{$\begin{array}{l}\text { Cost leadership } \\
\text { competitive advantage }\end{array}$} & CCA1 & $\begin{array}{l}\text { Our environmentally friendly products focus on } \\
\text { minimizing costs }\end{array}$ & \\
\hline & $\begin{array}{l}\text { CCA2 } \\
\text { CCA3 }\end{array}$ & $\begin{array}{l}\text { We focus on improving our productivity } \\
\text { We utilize economies of scale }\end{array}$ & \\
\hline \multirow{6}{*}{ Product performance } & PRP1 & Higher quality & \\
\hline & PRP2 & Higher reliability & \\
\hline & PRP3 & Greater customer support & \\
\hline & PRP4 & More added value to products & \\
\hline & PRP5 & Higher product flexibility & \\
\hline & PRP6 & More reasonable price & \\
\hline \multirow{5}{*}{$\begin{array}{l}\text { Strategic performance } \\
\text { (in the last } 3 \text { years) }\end{array}$} & SP1 & Higher customer satisfaction level & \multirow{11}{*}{$\begin{array}{l}\text { Adapted from } \\
\text { Nadkarni and } \\
\text { Narayanan [40] }\end{array}$} \\
\hline & SP2 & Greater growth & \\
\hline & SP3 & Higher market share & \\
\hline & SP4 & More positive effects to environment & \\
\hline & SP5 & Lower cost & \\
\hline & PPE1 & More efficient production systems & \\
\hline Production & PPE2 & Shorter time for launching new products & \\
\hline Performance & PPE3 & Higher quality of production processes & \\
\hline \multirow{3}{*}{ Financial performance } & FP1 & Better profit margins & \\
\hline & FP2 & Better value for shareholders & \\
\hline & FP3 & More efficient cash flow & \\
\hline
\end{tabular}

Note: Product refers to physical products for manufacturing firms and services for service firms. Production process/performance refers to manufacturing-based process/performance for manufacturing firms and service production process/performance for service firms [79]. Relevant items were modified to reflect the nature of firm industries. 


\section{Appendix B}

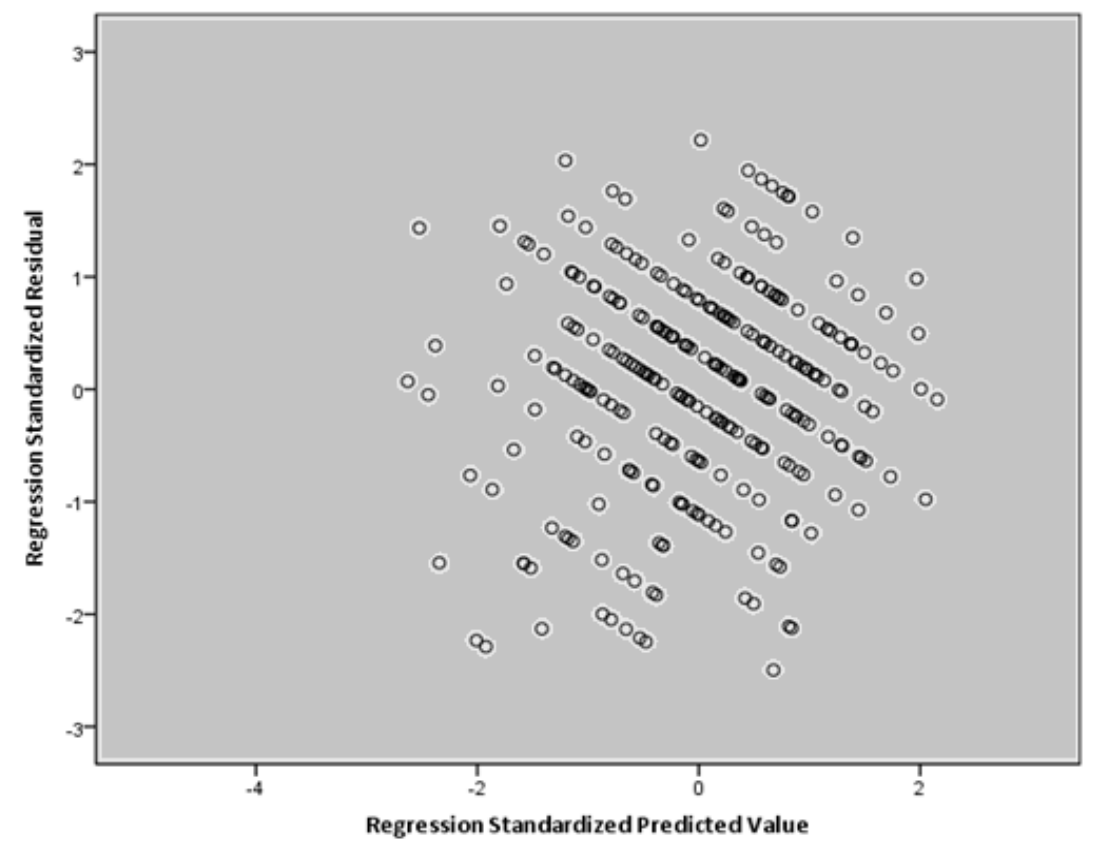

Figure A1. Scatterplot.

\section{References}

1. Olson, E.G. Creating an enterprise-level "green" strategy. J. Bus. Strategy 2008, 29, 22-30. [CrossRef]

2. Katsikeas, C.S.; Leonidou, C.N.; Zeriti, A. Eco-friendly product development strategy: Antecedents, outcomes, and contingent effects. J. Acad. Mark. Sci. 2016, 44, 660-684. [CrossRef]

3. De Marchi, V.; Di Maria, E.; Micelli, S. Environmental strategies, upgrading and competitive advantage in global value chains. Bus. Strategy Environ. 2013, 22, 62-72. [CrossRef]

4. Gupta, H.; Barua, M.K. A framework to overcome barriers to green innovation in smes using bwm and fuzzy topsis. Sci. Total Environ. 2018, 633, 122-139. [CrossRef]

5. Blanco, E.; Rey-Maquieira, J.; Lozano, J. The economic impacts of voluntary environmental performance of firms: A critical review. J. Econ. Surv. 2009, 23, 462-502. [CrossRef]

6. Clarkson, P.M.; Li, Y.; Richardson, G.D.; Vasvari, F.P. Does it really pay to be green? Determinants and consequences of proactive environmental strategies. J. Account. Public Policy 2011, 30, 122-144. [CrossRef]

7. King, A.A.; Lenox, M.J. Does it really pay to be green? J. Ind. Ecol. 2001, 5, 105-116. [CrossRef]

8. Orsato, R.J. Competitive environmental strategies: When does it pay to be green? Calif. Manag. Rev. 2006, 48, 127-143. [CrossRef]

9. Stefan, A.; Paul, L. Does it pay to be green? A systematic overview. Acad. Manag. Perspect. 2008, 22 , 45-62. [CrossRef]

10. Biçakcıŏ̆lu, N. Green business strategies of exporting manufacturing firms: Antecedents, practices, and outcomes. J. Glob. Mark. 2018, 31, 246-269. [CrossRef]

11. Fousteris, A.; Didaskalou, E.; Tsogas, M.-M.; Georgakellos, D. The environmental strategy of businesses as an option under recession in greece. Sustainability 2018, 10, 4399. [CrossRef]

12. Ko, W.W.; Liu, G. Environmental Strategy and Competitive Advantage: The Role of Small- and Medium-Sized enterprises' Dynamic Capabilities. Bus. Strategy Environ. 2017, 26, 584-596. [CrossRef]

13. Lee, S.Y.; Rhee, S.K. The change in corporate environmental strategies: A longitudinal empirical study. Manag. Decis. 2007, 45, 196-216. [CrossRef]

14. Murillo-Luna, J.L.; Garcés-Ayerbe, C.; Rivera-Torres, P. Barriers to the adoption of proactive environmental strategies. J. Clean. Prod. 2011, 19, 1417-1425. [CrossRef]

15. Bae, H.S. The effect of environmental capabilities on environmental strategy and environmental performance of korean exporters for green supply chain management. Asian J. Shipp. Logist. 2017, 33, 167-176. [CrossRef] 
16. Delmas, M.; Hoffmann, V.H.; Kuss, M. Under the tip of the iceberg: Absorptive capacity, environmental strategy, and competitive advantage. Bus. Soc. 2011, 50, 116-154. [CrossRef]

17. Do, B.; Nguyen, U.; Nguyen, N.; Johnson, L.W. Exploring the proactivity levels and drivers of environmental strategies adopted by vietnamese seafood export processing firms: A qualitative approach. Sustainability 2019, 11, 3964. [CrossRef]

18. Ge, B.; Yang, Y.; Jiang, D.; Gao, Y.; Du, X.; Zhou, T. An empirical study on green innovation strategy and sustainable competitive advantages: Path and boundary. Sustainability 2018, 10, 3631. [CrossRef]

19. López-Gamero, M.D.; Molina-Azorín, J.F.; Claver-Cortés, E. The whole relationship between environmental variables and firm performance: Competitive advantage and firm resources as mediator variables. J. Environ. Manag. 2009, 90, 3110-3121. [CrossRef]

20. Jiang, Y.; Xue, X.; Xue, W. Proactive corporate environmental responsibility and financial performance: Evidence from chinese energy enterprises. Sustainability 2018, 10, 964. [CrossRef]

21. Junquera, B.; Barba-Sánchez, V. Environmental proactivity and firms' performance: Mediation effect of competitive advantages in spanish wineries. Sustainability 2018, 10, 2155. [CrossRef]

22. Molina-Azorín, J.F.; Claver-Cortés, E.; López-Gamero, M.D.; Tarí, J.J. Green management and financial performance: A literature review. Manag. Decis. 2009, 47, 1080-1100. [CrossRef]

23. Primc, K.; Čater, T. The influence of organizational life cycle on environmental proactivity and competitive advantage: A dynamic capabilities view. Organ. Environ. 2015, 29, 212-230. [CrossRef]

24. Sambasivan, M.; Bah, S.M.; Jo-Ann, H. Making the case for operating "green": Impact of environmental proactivity on multiple performance outcomes of malaysian firms. J. Clean. Prod. 2013, 42, 69-82. [CrossRef]

25. Leonidou, L.C.; Christodoulides, P.; Kyrgidou, L.P.; Palihawadana, D. Internal drivers and performance consequences of small firm green business strategy: The moderating role of external forces. J. Bus. Ethics 2017, 140, 585-606. [CrossRef]

26. Roy, M. Environmental performance as a basis for competitive strategy: Opportunities and threats. Corp. Environ. Strategy 2002, 8, 339-347. [CrossRef]

27. Ryszko, A. Proactive environmental strategy, technological eco-innovation and firm performance-case of poland. Sustainability 2016, 8, 156. [CrossRef]

28. Dai, J.; Cantor, D.E.; Montabon, F.L. Examining corporate environmental proactivity and operational performance: A strategy-structure-capabilities-performance perspective within a green context. Int. J. Prod. Econ. 2017, 193, 272-280. [CrossRef]

29. Leonidou, L.C.; Fotiadis, T.A.; Christodoulides, P.; Spyropoulou, S.; Katsikeas, C.S. Environmentally friendly export business strategy: Its determinants and effects on competitive advantage and performance. Int. Bus. Rev. 2015, 24, 798-811. [CrossRef]

30. Leonidou, L.C.; Katsikeas, C.S.; Fotiadis, T.A.; Christodoulides, P. Antecedents and consequences of an eco-friendly export marketing strategy: The moderating role of foreign public concern and competitive intensity. J. Int. Mark. 2013, 21, 22-46. [CrossRef]

31. López-Gamero, M.D.; Molina-Azorín, J.F. Environmental management and firm competitiveness: The joint analysis of external and internal elements. Long Range Plan. 2016, 49, 746-763. [CrossRef]

32. Aragón-Correa, J.A.; Hurtado-Torres, N.; Sharma, S.; García-Morales, V.J. Environmental strategy and performance in small firms: A resource-based perspective. J. Environ. Manag. 2008, 86, 88-103. [CrossRef] [PubMed]

33. Nulkar, G. SMEs and environmental performance-A framework for green business strategies. Procedia Soc. Behav. Sci. 2014, 133, 130-140. [CrossRef]

34. Claver-Cortés, E.; Molina-Azorin, J.F.; Pereira-Moliner, J.; López-Gamero, M.D. Environmental strategies and their impact on hotel performance. J. Sustain. Tour. 2007, 15, 663-679. [CrossRef]

35. Fraj, E.; Matute, J.; Melero, I. Environmental strategies and organizational competitiveness in the hotel industry: The role of learning and innovation as determinants of environmental success. Tour. Manag. 2015, 46, 30-42. [CrossRef]

36. Molina-Azorín, J.F.; Tarí, J.J.; Pereira-Moliner, J.; López-Gamero, M.D.; Pertusa-Ortega, E.M. The effects of quality and environmental management on competitive advantage: A mixed methods study in the hotel industry. Tour. Manag. 2015, 50, 41-54. [CrossRef]

37. Atkin, T.; Gilinsky, A.; Newton, S.K. Environmental strategy: Does it lead to competitive advantage in the us wine industry? Int. J. Wine Bus. Res. 2012, 24, 115-133. [CrossRef] 
38. Barba-Sánchez, V.; Atienza-Sahuquillo, C. Environmental proactivity and environmental and economic performance: Evidence from the winery sector. Sustainability 2016, 8, 1014. [CrossRef]

39. Wright, M.; Filatotchev, I.; Hoskisson, R.E.; Peng, M. Strategic research in emerging markets: Challenging the conventional wisdom. J. Manag. Stud. 2005, 42, 1-33. [CrossRef]

40. Nadkarni, S.; Narayanan, V.K. Strategic schemas, strategic flexibility, and firm performance: The moderating role of industry clockspeed. Strateg. Manag. J. 2007, 28, 243-270. [CrossRef]

41. General Statistic Office of Vietnam. Statistical Summary Book of Vietnam; Statistical Publishing House: Hanoi, Vietnam, 2018.

42. Bansal, P.; Roth, K. Why companies go green: A model of ecological responsiveness. Acad. Manag. J. 2000, 43, 717-736.

43. Buysse, K.; Verbeke, A. Proactive environmental strategies: A stakeholder management perspective. Strateg. Manag. J. 2003, 24, 453-470. [CrossRef]

44. Henriques, I.; Sadorsky, P. The relationship between environmental commitment and managerial perceptions of stakeholder importance. Acad. Manag. J. 1999, 42, 87-99.

45. Elijido-Ten, E. Applying stakeholder theory to analyze corporate environmental performance: Evidence from australian listed companies. Asian Rev. Account. 2007, 15, 164-184. [CrossRef]

46. Hart, S.L. A natural-resource-based view of the firm. Acad. Manag. Rev. 1995, 20, 986-1014. [CrossRef]

47. Hart, S.L.; Dowell, G. A natural-resource-based view of the firm: Fifteen years after. J. Manag. 2011, 37, 1464-1479.

48. Aragon, J. Strategic proactivity and firm approach to the natural environment. Acad. Manag. J. 1998, 41, 556-567.

49. Christmann, P. Effects of "best practices" of environmental management on cost advantage: The role of complementary. Acad. Manag. J. 2000, 43, 663-680.

50. Sharma, S.; Vredenburg, H. Proactive corporate environmental strategy and the development of competitively valuable organizational capabilities. Strateg. Manag. J. 1998, 19, 729-753. [CrossRef]

51. Banerjee, S.B. Environmentalism: Interpretations from industry and. J. Manag. Stud. 2001, 38, 489-515. [CrossRef]

52. Liu, Y.; Guo, J.; Chi, N. The antecedents and performance consequences of proactive environmental strategy: A meta-analytic review of national contingency. Manag. Organ. Rev. 2015, 11, 521-557. [CrossRef]

53. Sharma, S. Managerial interpretations and orgainzational context as predcictors of corporate choice of environmental strategy. Acad. Manag. J. 2000, 43, 681-697.

54. Peteraf, M.A.; Barney, J.B. Unraveling the resource-based tangle. Manag. Decis. Econ. 2003, 24, 309-323. [CrossRef]

55. Porter, M.E. Competitive Advantage: Creating and Sustaining Superior Performance; The Free Press: New York, NY, USA, 1985.

56. Hill, C.W.L. Differentiation versus low cost or differentiation and low cost: A contingency framework. Acad. Manag. Rev. 1988, 13, 401-412. [CrossRef]

57. Newbert, S.L. Value, rareness, competitive advantage, and performance: A conceptual-level empirical investigation of the resource-based view of the firm. Strateg. Manag. J. 2008, 29, 745-768. [CrossRef]

58. Aragón-Correa, J.A.; Rubio-López, E.A. Proactive corporate environmental strategies: Myths and misunderstandings. Long Range Plan. 2007, 40, 357-381. [CrossRef]

59. Zeriti, A.; Robson, M.J.; Spyropoulou, S.; Leonidou, C.N. Sustainable export marketing strategy fit and performance. J. Int. Mark. 2014, 22, 44-66. [CrossRef]

60. Blomquist, J.; Bartolino, V.; Waldo, S. Price premiums for providing eco-labelled seafood: Evidence from msc-certified cod in sweden. J. Agric. Econ. 2015, 66, 690-704. [CrossRef]

61. Eryigit, N.; Özcüre, G. Eco-innovation as modern era strategy of companies in developing countries: Comparison between turkey and european union. Procedia Soc. Behav. Sci. 2015, 195, 1216-1225. [CrossRef]

62. Shrivastava, P. Environmental technologies and competitive advantage. Strateg. Manag. J. 1995, 16, 183-200. [CrossRef]

63. Banerjee, S.B.; Iyer, E.S.; Kashyap, R.K. Corporate environmentalism: Antecedents and influence of industry type. J. Mark. 2003, 67, 106-122. [CrossRef]

64. Chenhall, R.H. Integrative strategic performance measurement systems, strategic alignment of manufacturing, learning and strategic outcomes: An exploratory study. Account. Organ. Soc. 2005, 30, 395-422. [CrossRef] 
65. Arthur, J.B. Effects of human resource systems on manufacturing performance and turnover. Acad. Manag. J. 1994, 37, 670-687.

66. Moorman, C.; Rust, R.T. The role of marketing. J. Mark. 1999, 63, 180-197. [CrossRef]

67. Song, W.; Yu, H. Green innovation strategy and green innovation: The roles of green creativity and green organizational identity. Corp. Soc. Responsib. Environ. Manag. 2018, 25, 135-150. [CrossRef]

68. Dechant, K.; Altman, B. Environmental leadership: From compliance to competitive advantage. Acad. Manag. Perspect. 1994, 8, 7-27. [CrossRef]

69. Davidson, J.H. Offensive Marketing: Or, How to Make your Competitors Followers; Gower: Aldershot, UK, 1987.

70. Taylor, N.; Barker, K.; Simpson, M. Achieving 'sustainable business': A study of perceptions of environmental best practice by smes in south yorkshire. Environ. Plan. C Gov. Policy 2003, 21, 89-105. [CrossRef]

71. McConnell, J.D. The price-quality relationship in an experimental setting. J. Mark. Res. 1968, 5, 300-303. [CrossRef]

72. Wolinsky, A. Prices as signals of product quality. Rev. Econ. Stud. 1983, 50, 647-658. [CrossRef]

73. Gerstner, E. Do higher prices signal higher quality? J. Mark. Res. 1985, 22, 209-215. [CrossRef]

74. Cooper, R. Costing techniques to support corporate strategy: Evidence from japan. Manag. Account. Res. 1996, 7, 219-246. [CrossRef]

75. Darnall, N.; Henriques, I.; Sadorsky, P. Adopting proactive environmental strategy: The influence of stakeholders and firm size. J. Manag. Stud. 2010, 47, 1072-1094. [CrossRef]

76. Chen, Y.-S. The driver of green innovation and green image - green core competence. J. Bus. Ethics 2008, 81, 531-543. [CrossRef]

77. Brammer, S.; Hoejmose, S.; Marchant, K. Environmental management in smes in the uk: Practices, pressures and perceived benefits. Bus. Strategy Environ. 2012, 21, 423-434. [CrossRef]

78. Betts, T.K.; Wiengarten, F.; Tadisina, S.K. Exploring the impact of stakeholder pressure on environmental management strategies at the plant level: What does industry have to do with it? J. Clean. Prod. 2015, 92, 282-294. [CrossRef]

79. Wilson, A. Marketing Research; Macmillan International Higher Education: Great Britain, UK, 2018.

80. Agya Yalley, A.; Singh Sekhon, H. Service production process: Implications for service productivity. Int. J. Prod. Perform. Manag. 2014, 63, 1012-1030. [CrossRef]

81. González-Benito, J.; González-Benito, Ó. A review of determinant factors of environmental proactivity. Bus. Strategy Environ. 2006, 15, 87-102. [CrossRef]

82. Dang, C.; Li, Z.; Yang, C. Measuring firm size in empirical corporate finance. J. Bank. Financ. 2018, 86, 159-176. [CrossRef]

83. Podsakoff, P.M.; MacKenzie, S.B.; Lee, J.-Y.; Podsakoff, N.P. Common method biases in behavioral research: A critical review of the literature and recommended remedies. J. Appl. Psychol. 2003, 88, 879-903. [CrossRef]

84. Stump, R.L.; Heide, J.B. Controlling supplier opportunism in industrial relationships. J. Mark. Res. 1996, 33, 431-441. [CrossRef]

85. Nguyen, T.N.; Lobo, A.; Greenland, S. Pro-environmental purchase behaviour: The role of consumers' biospheric values. J. Retail. Consum. Serv. 2016, 33, 98-108. [CrossRef]

86. Nguyen, T.N.; Lobo, A.; Greenland, S. The influence of cultural values on green purchase behaviour. Mark. Intell. Plan. 2017, 35, 377-396. [CrossRef]

87. Das, A.K.; Biswas, S.R.; Abdul Kader Jilani, M.M.; Uddin, M.A. Corporate environmental strategy and voluntary environmental behavior-Mediating effect of psychological green climate. Sustainability 2019, 11, 3123. [CrossRef]

88. Nguyen, T.T.H.; Yang, Z.; Nguyen, N.; Johnson, L.W.; Cao, T.K. Greenwash and green purchase intention: The mediating role of green skepticism. Sustainability 2019, 11, 2653. [CrossRef]

89. Ateş, M.A.; Bloemhof, J.; Van Raaij, E.M.; Wynstra, F. Proactive environmental strategy in a supply chain context: The mediating role of investments. Int. J. Prod. Res. 2012, 50, 1079-1095. [CrossRef]

90. Sharma, S.; Durvasula, S.; Dillon, W.R. Some results on the behavior of alternate covariance structure estimation procedures in the presence of non-normal data. J. Mark. Res. 1989, 26, 214-221. [CrossRef]

91. Hair, J.F.; Black, W.C.; Babin, B.J.; Anderson, R.E. Multivariate Data Analysis, 7th ed.; Prentice Hall: Upper Saddle River, NJ, USA, 2010.

92. Hu, L.t.; Bentler, P.M. Cutoff criteria for fit indexes in covariance structure analysis: Conventional criteria versus new alternatives. Struct. Equ. Model. A Multidiscip. J. 1999, 6, 1-55. [CrossRef] 
93. Stevens, J.P. Outliers and Influential Data Points in Regression Analysis. Psychol. Bull. 1984, 95, 334-344. [CrossRef]

94. Conway, J.M.; Lance, C.E. What reviewers should expect from authors regarding common method bias in organizational research. J. Bus. Psychol. 2010, 25, 325-334. [CrossRef]

95. Fornell, C.; Larcker, D.F. Evaluating structural equation models with unobservable variables and measurement error. J. Mark. Res. 1981, 18, 39-50. [CrossRef]

96. Bagozzi, R.P.; Yi, Y. Assessing method variance in multitrait-multimethod matrices: The case of self-reported affect and perceptions at work. J. Appl. Psychol. 1990, 75, 547-560. [CrossRef]

97. Bentler, P.M. EQS 6 Structural Equations Program Manual; Multivariate Software, Inc.: Encino, CA, USA, 2006.

98. Tong, X.; Zhang, Z.; Yuan, K.-H. Evaluation of Test Statistics for Robust Structural Equation Modeling With Nonnormal Missing Data. Struct. Equ. Model. A Multidiscip. J. 2014, 21, 37-41. [CrossRef]

99. Yuan, K.; Bentler, P.M. Three Likelihood-Based Methods for Mean and Covariance Structure Analysis with Nonnormal Missing Data. Sociol. Methodol. 2000, 30, 165-200. [CrossRef]

100. Miles, M.P.; Covin, J.G. Environmental marketing: A source of reputational, competitive, and financial advantage. J. Bus. Ethics 2000, 23, 299-311. [CrossRef]

101. Aragón-Correa, J.A.; Sharma, S. A contingent resource-based view of proactive corporate environmental strategy. Acad. Manag. Rev. 2003, 28, 71-88. [CrossRef]

102. Miles, M.P.; Covin, J.G.; Heeley, M.B. The relationship between environmental dynamism and small firm structure, strategy, and performance. J. Mark. Theory Pract. 2015, 8, 63-78. [CrossRef]

103. Sen, P.; Roy, M.; Pal, P. Exploring role of environmental proactivity in financial performance of manufacturing enterprises: A structural modelling approach. J. Clean. Prod. 2015, 108, 583-594. [CrossRef]

104. Nguyen, N.; Greenland, S.; Lobo, A.; Nguyen Hoang, V. Demographics of sustainable technology consumption in an emerging market: The significance of education to energy efficient appliance adoption. Soc. Responsib. J. 2019, 15, 803-818. [CrossRef]

105. Finisterra do Paço, A.M.; Raposo, M.L.B. Green consumer market segmentation: Empirical findings from portugal. Int. J. Consum. Stud. 2010, 34, 429-436. [CrossRef]

106. Wang, M.-L.; Kuo, T.-C.; Liu, J.-W. Identifying target green 3c customers in taiwan using multiattribute utility theory. Expert Syst. Appl. 2009, 36, 12562-12569. [CrossRef]

(C) 2020 by the authors. Licensee MDPI, Basel, Switzerland. This article is an open access article distributed under the terms and conditions of the Creative Commons Attribution (CC BY) license (http://creativecommons.org/licenses/by/4.0/). 